\title{
SISTEM PENGAJUAN JUDUL TUGAS AKHIR DENGAN MENGGUNAKAN METODE TERM WEIGHTING
}

\author{
Tri Yuliati ${ }^{1}$, Erna Alimudin ${ }^{2}$, Fitra $^{3}$ \\ 1)Program Studi Informatika, Sekolah Tinggi Teknologi Dumai \\ Jl. Utama Karya Bukit Batrem II \\ Email: triyuliati00@gmail.com@mail.com
}

\begin{abstract}
ABSTRAK
Pengajuan judul tugas akhir merupakan hal yang pertama dilakukan mahassiswa untuk melakukan penelitian dan menyelesaikan kuliah di Sekolah Tinggi Teknologi (STT) Dumai, maka dari itu proses pengajuan tugas akhir harus benarbenar dipilih judul yang sesuai untuk pengajuan penelitian dikarenakan menghindari terjadinya kesamaan judul yang sering terjadi., sehingga bisa meminimalisir terjadinya plagiarisme. Selama ini proses yang berjalan cukup lambat untuk penerimaan judul tugas akhir yang masuk dikarenakan proses pengajuan masih manual yaitu dengan menggunakan kertas proposal dari mahasiswa yang diajukan ke prodi, kendala lainnya yaitu dengan minimnya informasi yang didapatkan mengenai judul tugas akhir yang sudah pernah ada. maka dari itu penulis membuat penelitian mengenai pengajuan judul tugas akhir dengan metode term weighting pada sistem informasi pengajuan judul tugas akhir dengan menggunakan bahasa pemrograman PHP dimana metode term weighting ini menghitung judul yang diinput kedalam sistem dengan perhitungan jika judul yang dimasukkan melebihi $50 \%$ dari judul yang sudah ada maka judul yang diajukan tidak layak dengan nilai persentasi kelayakan kecil dan mahasiswa tidak bisa mengajukan judul yang sama, sistem ini juga menambahkan kata pengecualian yaitu kata yang sering diajukan mahasiswa menjadi kata yang tidak ada nilai persentasi kelayakan.
\end{abstract}

Kata kunci: Judul Tugas Akhir, Term Weighting, Sistem

\begin{abstract}
Submission of the title of the final task is the first thing done for students to do research and finish college at Dumai High School Technology (STT), therefore the process of filing the final task should be selected the appropriate title for the submission of research because it avoids the occurrence of common title that often happens, so it can minimize the occurrence of plagiarism. During this process is running slow enough to accept the title of the final project entry because the submission process is still manual that is by using the proposal
\end{abstract}


paper from students who submitted to the study program, other obstacles is the lack of information obtained about the title of the final task that has ever existed. therefore the authors make research on the submission of the title of the final task with the method of term weighting on information systems filing the title of the final task using PHP programming language where the method of term weighting is calculate the title entered into the system with the calculation if the title entered exceeds $50 \%$ of the title already existed then the title submitted is not feasible with a small feasibility percentage score and the student can not submit the same title, the system also adds the exception word that is the word that is often asked by the student to be a word that has no feasibility percentage value.

Keywords: Final Project (Thesis) Title, Term Weighting, System

\section{Pendahuluan}

Perguruan tinggi merupakan tempat proses belajar mengajar untuk menyelesaikan pendidikan strata satu (s1), untuk bisa menyelesaikan kuliah s1 mahasiswa wajib untuk menyelesaikan tugas akhirnya. untuk menyelesaikannya langkah awalnya adalah dengan mengajukan judul tugas akhir, untuk menentukan judul tugas akhir yang layak. Ada beberapa kendala yang menjadi permasalahan yaitu minimnya informasi untuk mengetahui judul-judul yang pernah diajukan oleh mahasiswa terdahulu dan ini menjadi salah satu kendala bagi mahasiswa di STT Dumai dimana proses pengajuan judul yang berjalan juga masih menggunakan proses manual yaitu dengan memberikan berkas proposal ke prodi. sehingga cara ini kurang efektif dari segi waktu dan informasi.

Penelitian serupa yang dilakukan oleh mas'udia, 2017 peneliti ini akan mengembangkan suatu sistem temu kembali informasi judul tugas akhir dan perhitungan kemiripan dokumen menggunakan vector space model. Sistem secara otomatis akan melakukan indexing secara offline dan temu kembali (retrieval) secara real time. Proses retrieval dimulai dengan mengambil query dari pengguna, menerapkan stop word removal sehingga dihasilkan keyword yang compaq tetapi dapat mewakili query tersebut, kemudian sistem menghitung kemiripan antara keyword dengan daftar dokumen yang diwakili oleh term-term di dalam index. Dokumen akan ditampilkan diurutkan berdasarkan dokumen yang paling mirip. Dengan menggunakan yang sama yaitu metode Term Weighting, peneliti Fauzi, 2014 melakukan penelitian yang menghasilkan metode baru Term Weighting yang berbasis pada indeks buku dan kelas. Metode ini memperhatikan frekuensi kemunculan term pada keseluruhan buku dan kelas. Metode yang disebut inverse class frequency (ICF) dan inverse book frequency (IBF) ini digabungkan dengan metode sebelumnya sehingga menjadi TF.IDF.ICF.IBF. 
Pengujian metode ini menggunakan dataset dari beberapa $e$-book berbahasa arab.

Teori sistem melahirkan konsep-konsep futuristik, antara lain yang terkenal adalah konsep sibernetika (cybernetics). Konsep atau bidang kajian ilmiah ini terutama berkaitan dengan upaya-upaya untuk menerapkan berbagai disiplin ilmu, yaitu ilmu perilaku, fisika, biologi dan teknik. Unsurunsur yang mewakili suatu sistem secara umum adalah masukan (input), pengolahan (processing) dan keluaran (output) (Sutabri, 2012).

Term weighting adalah prosedur yang berlangsung selama proses pengindeksan teks untuk menilai nilai setiap istilah pada dokumen. Pembobotan bobot adalah penugasan nilai numerik dengan istilah yang mewakili kepentingan mereka dalam dokumen untuk meningkatkan keefektifan pengambilan. Salton (1998). Intinya, ini mempertimbangkan pentingnya kata-kata individual dalam sistem pencarian informasi, yang dapat meningkatkan keefektifan sistem, karena tidak semua persyaratan dalam koleksi dokumen tertentu sama pentingnya. Menimbang persyaratan adalah sarana yang memungkinkan sistem pengambilan untuk menentukan pentingnya istilah tertentu dalam dokumen atau kueri tertentu. Ini adalah komponen penting dari setiap sistem pencarian informasi, komponen yang telah menunjukkan potensi besar untuk meningkatkan keefektifan pengambilan kembali sistem pencarian informasi. Salton (1983)

Semakin sedikit jumlah dokumen yang mengandung term yang dimaksud, maka nilai idf semakin besar. Nilai idf sebuah term dirumuskan dalam persamaan berikut:

$$
i d f=\log \frac{n}{d f}
$$

Keterangan rumus (1) adalah sebagai berikut.

idf : nilai inverse document frequency

$\mathrm{n}$ : jumlah dokumen di dalam koleksi;

df: nilai document frequency

Penghitungan bobot dari term tertentu dalam sebuahdokumen dengan menggunakan perkalian nilai tf dan idfmenunjukkan bahwa deskripsi terbaik dari dokumenadalah term yang banyak muncul dalam dokumentersebut dan sangat sedikit muncul pada dokumen yang lain. Perhitungan bobot term adalah sebagai berikut :

$$
\beta=(t f) *(i d f)
$$

Keterangan rumus (2) adalah sebagai berikut.

$B$ : nilai bobot term ;

tf : nilai term frequency

idf : nilai inverse document frequency.

Tingkat kemiripan term pada dokumen yang dicari dapat dituliskan pada persamaan Rocchio relevance feedback berikut ini (Pausta, 2013) : 


$$
R=N+\beta\left(\left(\frac{D p}{N p}\right)-\left(\frac{D n}{N n}\right)\right)
$$

Keterangan rumus (3) adalah sebagai berikut.

$\mathrm{R}$ : Tingkat kemiripan term ;

$\mathrm{N}$ : Jumlah term tiap dokumen ;

$B$ : nilai bobot term;

Dp : Term dari dokumen relevan ;

$\mathrm{Np}$ : Jumlah dokumen relevan ;

Dn : Term dari dokumen tak relevan ;

Nn : Jumlah dokumen tak relevan

\section{MetodePenelitian}

Pengembangan sistem yang berbasis komputer dapat merupakan tugas kompleks yang membutuhkan banyak sumber daya dan dapat memakan waktu berbulan-bulan bahkan bertahun-tahun untuk menyelesaikannya. Proses pengembangan sistem melewati beberapa tahapan dari mulai sistem itu di rencanakan sampai dengan sistem itu diterapkan, dioperasikan dan dipelihara.

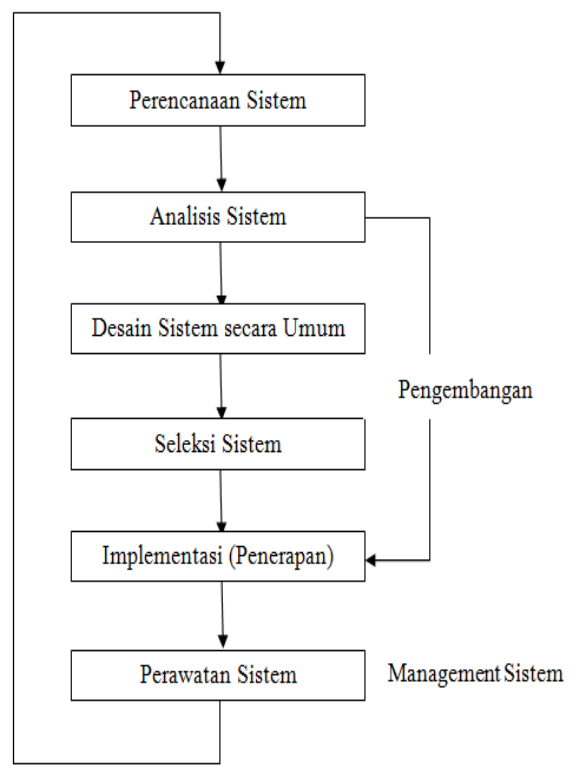

Gambar 2. Siklus hidup pengembangan sistem.

Adapun gambaran umum yang telah dilakukan penelitian pada sistem informasi pengajuan judul skripsi pada Gambar 2. Skripsi berbabis web ini dibangun dengan menggunakan bahasa pemrograman HTML, PHP, CSS, serta JavaScript dan untuk database menggunakan XAMPP versi 3.2.2 
dengan browser Mozilla Firefox, chrome dan opera. Sistem Informasi Manajemen Tugas Akhir ini antara lain adalah membantu dalam pengelolaan data Tugas Akhir, mulai dalam pendaftaran judul Skripsi, penentuan judul mahasiswa menggunakan metode term weigting dengan memperkecil judul Skripsi yang sama, dan menentukan dosen pembimbing. sehingga waktu yang dibutuhkan mahasiswa tidak lama dan informasi mengenai judul yang akan diajukan bisa dilihat didalam sistem pengajuan judul tugas akhir.

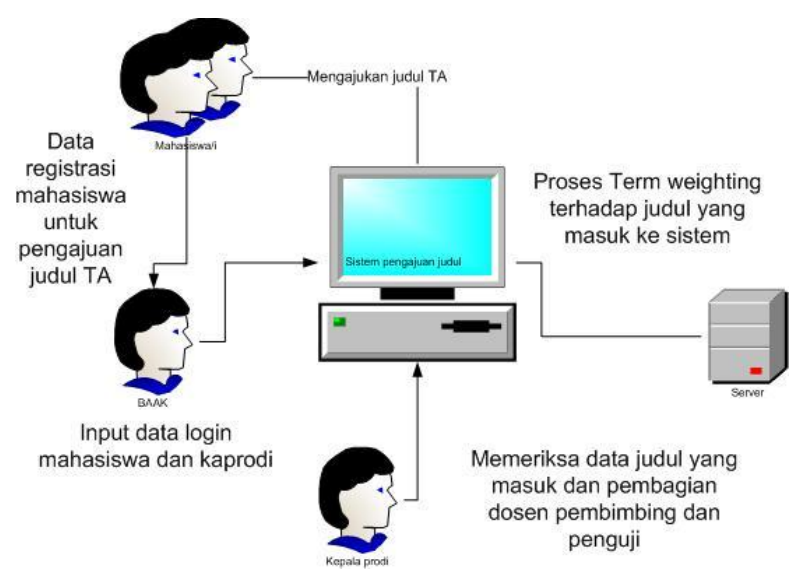

Gambar 2. Gambaran Umum Sistem Pengajuan Judul Tugas Akhir

\section{Hasil dan Pembahasan}

Rancangan penelitian yang akan dilakukan menggunakan beberapa entitas yang terkait yaitu BAAK, mahasiswa, Kaprodi. hasil dari ouput yang dihasilkan merupakan sistem yang bisa mendeteksi kesamaan judul dari pengajuan judul skripsi mahasiswa. Adapun rancangan yang akan dibuat dirujuk pada Gambar 3. 


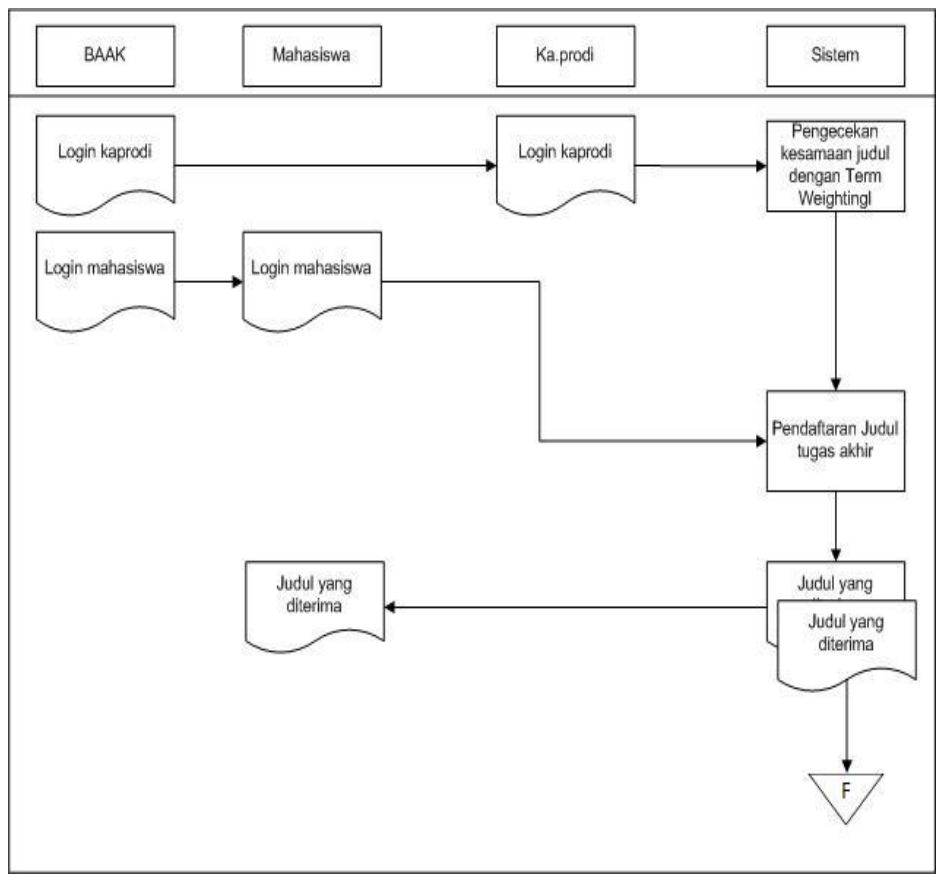

Gambar 3. Aliran Sistem Informasi pengajuan Judul Tugas Akhir

Petugas BAAK juga memberikan hak akses kepada masing-masing Kaprodi dan mahasiswa mendapatkan akses login dan memperbaiki isi data profil. Setelah itu mahasiswa dapat mengajukan judul seperti pada gambar 4. Kaprodi melakukan pengecekan judul skripsi mahasiswa dan menetapkan dosen pembimbing mahasiswa skripsi yang dirujuk pada gambar 5. Kaprodi dapat melihat kelayakan judul skripsi mahasiswa dengan menggunakan metode term weighting yaitu pada gambar 6

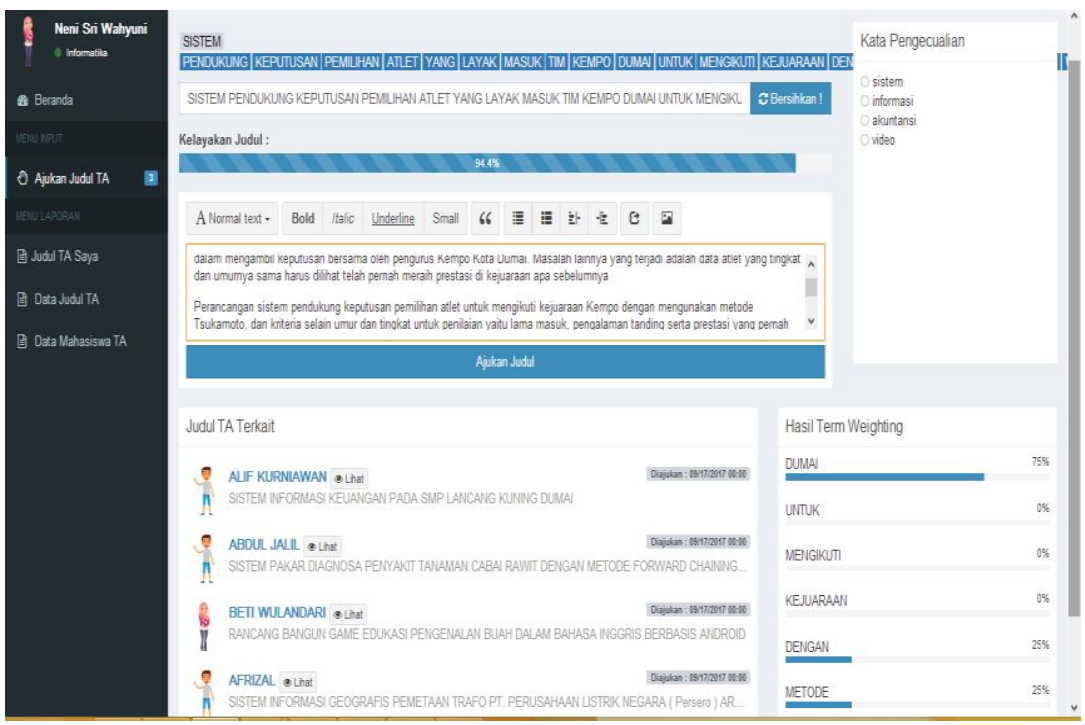

Gambar 4. Pengajuan Judul Skripsi Mahasiswa 
Kaprodi dapat melihat dan memeriksa hasil judul TA mahasiswa yang telah mendaftar, apakah layal atau tidak. sehingga bisa diterima atau ditolak. jika judul mahasiswa tersebut diterima maka kaprodi memberikan dosen pembimbing untuk skripsi tersebut.

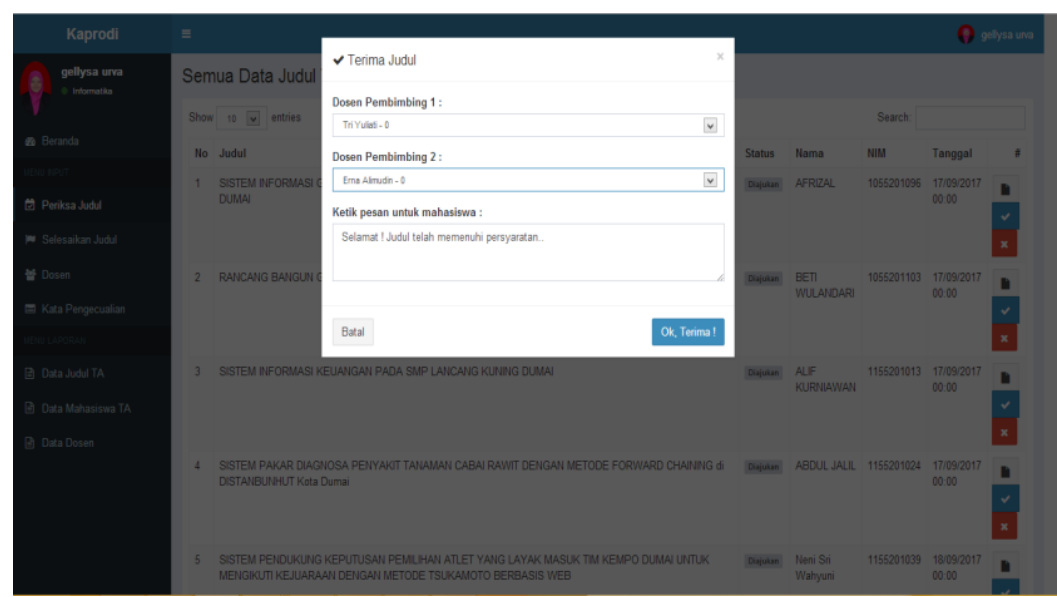

Gambar 5. Penerimaan Judul TA Dan Dosen Pembimbing

Dosen pembimbing ditentukan oleh kaprodi agar pembagian bimbingan mahasiswa terbagi dengan adil tiap dosennya. dosen akan mengetahui mahasiswa bimbingannya dari print out hasil laporan yang diberikan oleh kaprodi. dosen berkewajiban membimbing mahasiswa hingga selesai menyelesaikan skripsinya.

Langkah pertama dalam metode Term Weighting adalah menghitung nilai tiap term pada judul yang diajukan dengan judul-judul yang sudah diajukan sebelumnya.Bila ditemukan term yang serupa maka bernilai satu, bila tidak bernilai nol. Berikut satu contoh judul yang diajukan dengan membandingkan terhadap tujuh judul yang sudah diajukan.Hasilnya dapat dilihat pada Tabel 1.

Tabel 1. Daftar Judul yang Diajukan dan yang telah Diajukan

\begin{tabular}{|c|c|c|c|c|c|c|c|c|c|c|c|}
\hline \multicolumn{8}{|c|}{ MASUKKAN JUDUL YANG DIAJUKAN } & \multirow[b]{2}{*}{ DENGAN } & \multirow[b]{2}{*}{ METODE } & \multirow[b]{2}{*}{ FORWARD } & \multirow[b]{2}{*}{ CHAINING } \\
\hline & SISTEM & PAKAR & DIAGNOSIS & PENYAKIT & TANAMAN & CABAI & RAWII & & & & \\
\hline Dokumen & \multicolumn{3}{|c|}{ JUDUL YANG SUDAH DLAJUKAN } & & & & & & & & \\
\hline \multirow[t]{2}{*}{ D1 } & SISTEM & INFORMASI & GEOGRAFIS & PEMETAAN & TRAFO & & & & & & \\
\hline & $\begin{array}{r}1 \\
\text { SISTEM }\end{array}$ & $\begin{array}{r}0 \\
\text { PAKAR }\end{array}$ & $\begin{array}{c}0 \\
\text { DLAGNOSIS }\end{array}$ & $\begin{array}{c}0 \\
\text { PENYAKIT }\end{array}$ & $\begin{array}{c}0 \\
\text { HEWAN }\end{array}$ & TERNAK & SAPI & MENGGUNA & METODE & CERTAINTY & FACTOR \\
\hline D2 & 1 & 1 & 1 & 0 & 0 & & 0 & 0 & 1 & 0 & 0 \\
\hline \multirow[t]{2}{*}{ D3 } & SISTEM & PENDUKUNG & KEPUTUSAN & JENIS & KONSERVA & MASALAH & GIGI & MENGGUNA & METODE & FORWARD & CHAINLNG \\
\hline & 1 & 0 & & 0 & 0 & 0 & 0 & 0 & 1 & 1 & 1 \\
\hline \multirow[t]{2}{*}{ D4 } & SISTEM & INFORMASI & GEOGRAFIS & PEMETAAN & PANGKALA & GAS & LPG & DAN & SPBU & & \\
\hline & 1 & 0 & & 0 & & 0 & 0 & 0 & 0 & & \\
\hline \multirow[t]{2}{*}{ D5 } & SISTEM & INFORMASI & GEOGRAFIS & RUMAH & KONTRAKA & & & & & & \\
\hline & 1 & 0 & 0 & 0 & 0 & & & & & & \\
\hline \multirow[t]{2}{*}{ D6 } & SISTEM & INFORMASI & PELAYANAN & KESEHATAN & PADA & KLINIK & & & & & \\
\hline & & & 0 & 0 & 0 & 0 & & & & & \\
\hline \multirow[t]{2}{*}{ D7 } & SISTEM & PENDUKUNG & KEPUTUSAN & PEMILIHAN & KARYAWA & TELADAN & MENGGUNAKAN & METODE & FORWARD & CHALNING & \\
\hline & 1 & 0 & 0 & & 0 & 0 & 0 & 1 & 1 & 1 & \\
\hline
\end{tabular}


Selanjutnya dilakukan penghitungan nilai $\omega$ (bobot).Hasilnya dapat dilihat pada Tabel 2.Dimana :

tf $=$ jumlah term yang serupa pada tiap-tiap judul

$\mathrm{df}=1 / \mathrm{tf}$

tf.idf $=\log \mathrm{N} / \mathrm{df}$

$\mathrm{N}=$ jumlah term pada judul yang diajukan

Pada contoh judul yang diajukan di atas jumlah term adalah 11

$\omega(\mathrm{N})=$ jumlah bobot judul yang diajukan pada tiap-tiap judul yang sudah diajukan

Tabel 2. Daftar Judul yang Diajukan dan yang telah Diajukan

\begin{tabular}{c|c|c|c|c}
\hline $\mathrm{D}$ & $\mathrm{tf}$ & $\mathrm{df}$ & $\mathrm{tf.idf}$ & $\omega(\mathrm{N})$ \\
\hline $\mathrm{D} 1$ & 1 & 1 & 1.04139 & 2.04139 \\
$\mathrm{D} 2$ & 3 & 0.33333 & 0.56427 & 2.69281 \\
$\mathrm{D} 3$ & 4 & 0.25 & 0.43933 & 2.75733 \\
$\mathrm{D} 4$ & 1 & 1 & 1.04139 & 2.04139 \\
$\mathrm{D} 5$ & 1 & 1 & 1.04139 & 2.04139 \\
$\mathrm{D} 6$ & 1 & 1 & 1.04139 & 2.04139 \\
$\mathrm{D} 7$ & 4 & 0.25 & 0.43933 & 2.75733
\end{tabular}

Terakhir, diambil tiga nilai tertinggi dari seluruh urutan judul (D) yang sudah diajukan berdasarkan nilai $\omega$ (bobot) terbesar.Hasilnya dapat dilihat pada Tabel 3 .

Tabel 3. Judul yang Serupa berdasarkan Hasil Perhitungan Nilai Bobot denganTerm Weighting

\begin{tabular}{|c|c|c|c|c|c|c|c|c|c|c|c|}
\hline \multicolumn{8}{|c|}{ MASUKKAN JUDUL YAN } & \multirow[b]{2}{*}{ DENGAN } & \multirow[b]{2}{*}{ METODE } & \multirow[b]{2}{*}{ FORWARD } & \multirow[b]{2}{*}{ CHAINING } \\
\hline & SISTEM & PAKAR & DIAGNOSIS & PENYAKIT & TANAMAN & CABAI & RAWIT & & & & \\
\hline$\omega(\mathrm{N})$ & JUDUL Y & SUDAH DIAJUK & & & & & & & & & \\
\hline 2.75733 & SISTEM & PENDUKUNG & KEPUTUSAN & PEMILIHAN & KARYAWA & IELADAN & MENGGUNAKAN & METODE & FORWARD & CHAINING & \\
\hline 2.75733 & SISTEM & PENDUKUNG & KEPUTUSAN & JENIS & KONSERVA & MASALAH & GIGI & MENGGUNA & METODE & FORWARD & CHAI \\
\hline 2.69281 & SISTEM & PAKAR & DLAGNOSIS & PENYAKIT & HEWAN & |TERNAK & SAPI & MENGGUNA & METODE & |CERTAINTY & FACTOR \\
\hline
\end{tabular}

Judul-judul tersebut adalah judul yang dinilai serupa berdasarkan metode Term Weighting. Hal ini yang akan dijadikan kaprodi sebagai bahan pertimbangan untuk menentukan diterima atau tidaknya judul yang diajukan mahasiswa. Sebagai kaprodi sistem pengajuan judul ini sangat membantu untuk meminimalisir terjadinya kesamaan judul yang akan diajukan oleh mahasiswa sehingga memperkecil terjadinya plagiarisme. kaprodi tetap mempunyai hak akses untuk menerima judul yang masuk walaupun persentasi kelayakan judul kecil. karena sistem tidak membatasi hak akses tersebut, karena sistem hanya memberikan rekomendasi kelayakan judul yang ada dengan judul sebelumnya. 


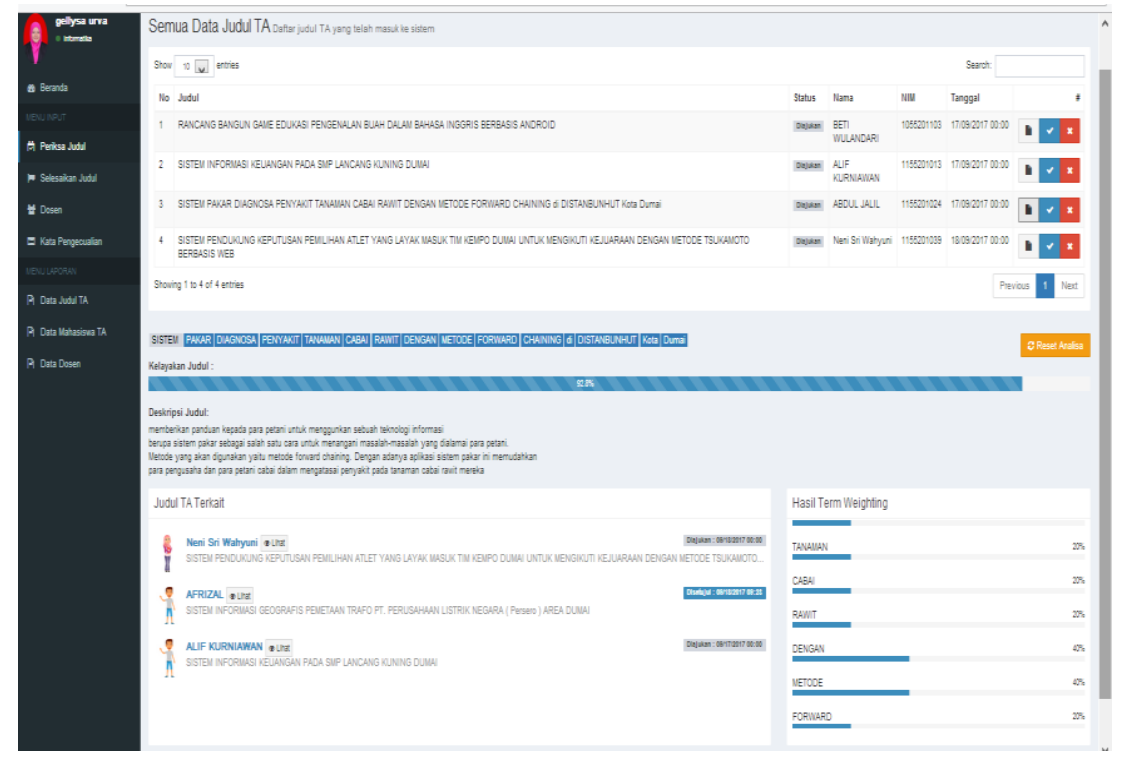

6. Kelayakan Judul Skripsi Mahasiswa

Sebagai kaprodi sistem pengajuan judul ini sangat membantu untuk meminimalisir terjadinya kesamaan judul yang akan diajukan oleh mahasiswa sehingga memperkecil terjadinya plagiarisme. kaprodi tetap mempunyai hak akses untuk menerima judul yang masuk walaupun persentasi kelayakan judul kecil. karena sistem tidak membatasi hak akases tersebut, karena sistem hanya memberikan rekomendasi kelayakan judul yang ada dengan judul sebelumnya.

Form pengajuan judul skripsi pada gambar 4, mahasiswa mengisi judul Skripsi, di form terdapat kata pengecualian yaitu kata yang telah diinput oleh kaprodi sebagai kata pengecualian yang sering diambil sebagai judul oleh mahasiswa. jika kata yang diajukan tidak terdapat pada pengecualian maka kata yang diinput masuk kedalam hasil term weigting jika kata yang diinput telah ada sebelumnya maka dibagi menjadi $50 \%$. Misalnya ada 2 kata yang pernah ada maka kata tersebut menjadi 50\%. jika kata yang diinput oleh mahasiswa tersebut melebihi dari \%nya maka kata tersebut masuk kedalam kata pengecualian.sehingga mahasiswa dapat melihat judul yang diambil layak atau tidak karena sistem bisa langsung membaca tingkat persentase kata yang telah masuk sebagai kata pengecualian dan term weighting. Persentasi kelayakan judul dapat dilihat logikanya pada tabel 1 coding kelayakan judul, jadi kata yang masuk ke term weighting di proses disimpan dalam bentuk javascript.

Tabel 3. Coding Kelayakan Judul 


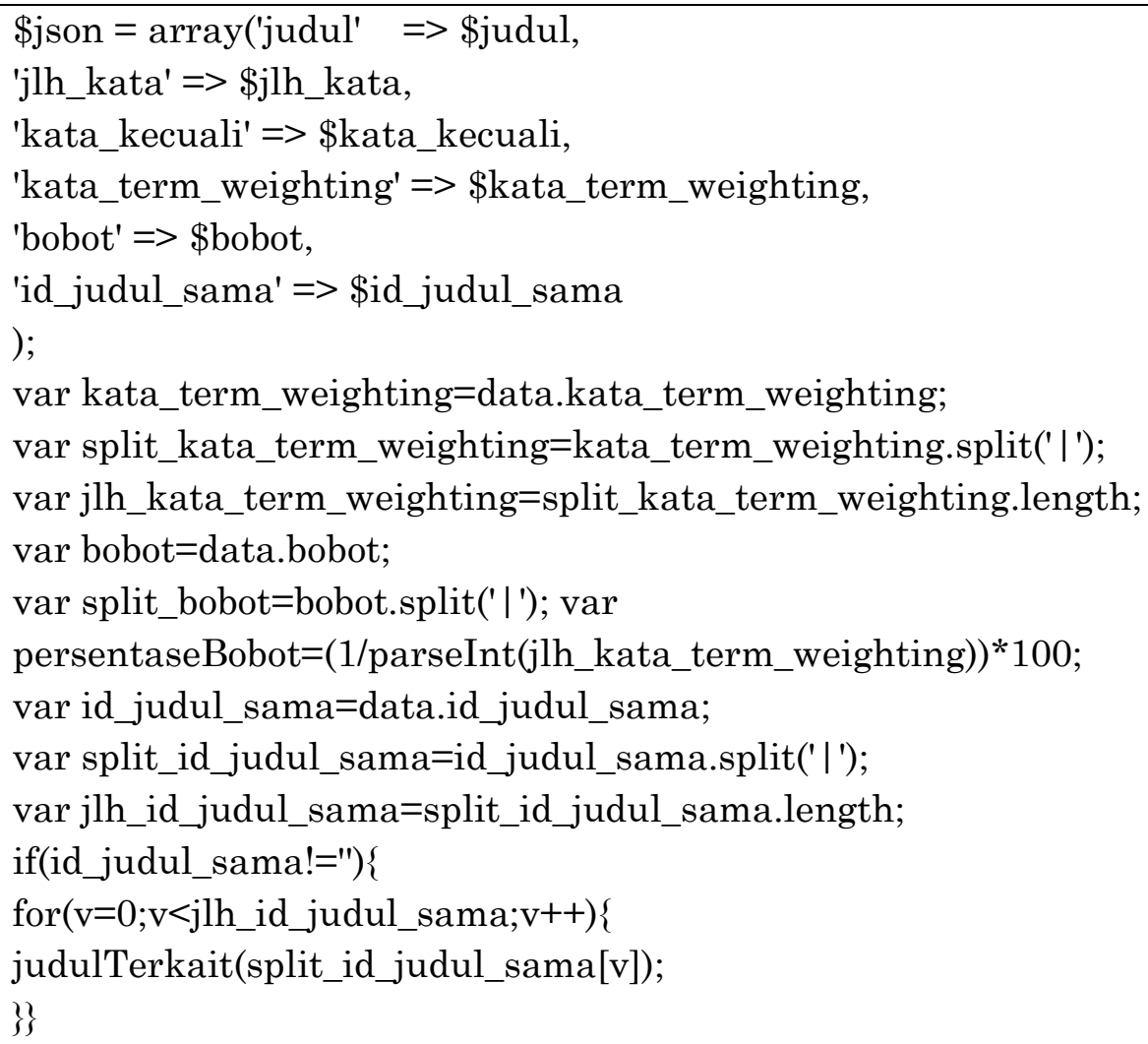

\section{Simpulan}

Sistem informasi yang telah diimplementasikan dapat membantu meminimalisir terjadinya kesamaan judul skripsi dengan menggunakan metode term Weighting, dimana sistem mampu mendeteksi secara otomatis kelayakan judul dalam persentase dari bobot kata Term Weighting. Sehingga membantu kaprodi dalam memberikan keputusan untuk kelayakan judul yang diajukan oleh mahasiswa. Sistem informasi pengajuan judul skripsi yang dibuat mampu menggantikan proses pengajuan judul skripsi secara manual. Kerja sistem akan semakin baik dalam mendeteksi kesamaan judul jika database judul skripsi ditambahkan sesuai dengan judul-judul yang telah diajukan. 


\section{DaftarPustaka}

Fauzi, M. Ali , Dr. Agus Zainal Arifin, S.Kom, Anny Yuniarti, 2014, Term Weighting Berbasis Indeks Buku dan Kelas untuk Perangkingan Dokumen Berbahasa Arab , LONTAR KOMPUTER VOL. 5, NO. 2, AGUSTUS 2014 ISSN: 2088-1541 Institut Teknologi Sepuluh Nopember

Mas'Udia, Putri Elfa (2017) Information Retrieval Tugas Akhir Dan Perhitungan Kemiripan Dokumen Mengacu Pada Abstrak Menggunakan Vector Space Model, Jurnal SIMETRIS, Vol 8 No 1 April 2017 ISSN: 2252-4983

Pausta Yugianus, 2013. Pengembangan Sistem Penelusuran Katalog Perpustakaan Dengan Metode Rocchio Relevance Feedback.Jurnal EECCIS Vol. 7, No. 1, Universitas Brawijaya, Malang.

Salton G. And Buckley C. (1988)Term-Weighting Approaches In Automatic Text

Retrieval.

Https: / Link.Springer.Com /Referenceworkentry/10.1007\%2F978-0387-39940-9_943\#CR7_943

Salton G. And Mcgill M. (1983) Introduction To Modern Information Retrieval. Mcgraw-Hill Book Company, New York, NY, Https: / /Link.Springer.Com /Referenceworkentry/10.1007\%2F978-0387-39940-9_943\#CR7_943

Sutabri, Tata, 2012, “Analisa Sistem Informasi”, Andi, Yogyakarta. 